RESEARCH ARTICLE

\title{
Assessment of Farmer's Perception on Pesticide Usage Pattern and Knowledge on Pest Management in Amaranthus in Coimbatore District
}

\author{
Elakkiya $\mathbf{S}^{1}$, Suganthy $\mathbf{M}^{{ }^{2}}$, Bhuvaneswari $\mathbf{K}^{1}$ and Rajasree $\mathbf{V}^{3}$ \\ ${ }^{1}$ Department of Agricultural Entomology, Tamil Nadu Agricultural University, Coimbatore - 641003 \\ ${ }^{2}$ Department of Sustainable Organic Agriculture, Tamil Nadu Agricultural University, Coimbatore - 641003 \\ ${ }^{3}$ Department of Vegetable Science, Tamil Nadu Agricultural University, Coimbatore - 641003
}

\begin{abstract}
Amaranthus is a protein rich grain that is commonly cultivated as a leafy vegetable. Insect pests (63.2\%), marketing (22.4\%) and weather parameters $(14.4 \%)$ acted as the major constraints in amaranthus production. Among the constraints, infestation by numerous insect pests that feed on different plant parts such as stem, leaves, flowers and seeds had greater negative impact on amaranthus production. A total number of 92 insect pests from 11 different orders have been documented in cultivated amaranthus. Among them, the leaf webber, Hymenia recurvalis Fab. (Crambidae : Lepidoptera) and stem weevil, Hypolixus truncatulus (Curculionidae: Coleoptera) were considered as major threat to the farmers. Leaf webber, H. recurvalis caused the maximum damage through webbing and defoliation up to $8.8 \%$. Stem weevil, $H$. truncatulus resulted in $12.6 \%$ damage, while, the damage was up to $7.3 \%$ due to white grub, the root feeder. Almost all the amaranthus farmers relied on chemical pesticides for the management of insect pests of amaranthus. A field survey on pesticide usage pattern in amaranthus was undertaken in three amaranthus growing blocks of Coimbatore district viz., Sultanpet, Karamadai and Thondamuthur. Most of the farmers $(73.3 \%)$ used chlorantraniliprole for managing the insect pests infesting amaranthus. Around 66 per cent of the farmers used organic pesticide (Exodus) as an alternate next to chlorantraniliprole. Percentage of farmers using imidacloprid, flubendiamide, panchakavya and jeevamrutham for crop protection represent 53.3, 33.3 and 13.3 per cent, respectively.
\end{abstract}

Keywords: Amaranthus; Pesticides usage pattern; Chlorantraniliprole; Organic pesticide.

\section{INTRODUCTION}

Amaranthus (Amaranthus spp) is widely cultivated as a leafy vegetable in India, grown during the summer and rainy seasons. New tender leaves and stems are used to make a delectable cooking preparation. Majority of amaranthus species are native to India or Indo-China region. In India, Amaranthus tricolour is the most widely cultivated species as leafy type. $A$. blitum and $A$. tristis are two other cultivated amaranthus species. It is more commonly cultivated in South India as a green leafy vegetable. Green leafy vegetables have gained general acceptance as a vital dietary component and they account for a significant amount of the diet in India's food preparation. It is an herbaceous annual plant. Amaranthus leaves are used as a vegetable and the seeds are used as a cereal (Ezeh et al., 2015). Vegetable amaranthus are popular because of their early maturity, palatability and nutritional content (Kamalanathan et al., 1973), as well as the fact that they may grow in urban garbage or compost (Achigan-Dako et al., 2014). The leaves are rich source of calcium, iron and vitamins, including vitamin $A$, vitamin $\mathrm{K}$, vitamin $\mathrm{B}_{6}$, vitamin $C$ and riboflavin (Akubugwo et al., 2007). On the other hand, grains are rich in dietary fibre, calcium and minerals like iron, magnesium, phosphorus, copper and manganese, as well as good source of essential amino acids, especially lysine. It aids in the reduction of blood pressure and cholesterol levels, as well as enhances antioxidant levels, and improves the immune systems (Martirosyan et al., 2007). As both vitamins and minerals are lacking in the diet of poor people, consumption of amaranthus helps in improving the health and livelihood of rural and urban poor people (Kaaya et al., 2017). The diversity of insect pests is one of the limiting factors impacting amaranthus yield (Aderolu et al., 2013). Amaranthus is affected by other orders besides 
Lepidoptera, including Coleoptera, Hemiptera and Orthoptera. Among different orders of insect pests, the lepidopteran pests primarily target amaranthus.

Despite its positive potential in human health and nutrition, amaranthus production is hindered by complex insect pests, of which amaranthus leaf webber and stem weevil are ranked as the most destructive pests (Kagali et al., 2013 and Othim et al., 2018). Sixty insect species associated with amaranthus crop were identified, among which $H$. recurvalis Fab. (Lepidoptera: Crambidae) having the highest percentage of incidence on the foliage up to $8.8 \%$. This leaf webber causes severe losses to amaranthus. The caterpillar webs the leaf into distinctive leaf shelter and voraciously feeds on the green matter. The most voracious and damaging stage of $H$. recurvalis is the third instar larva which prefers tender leaf. Severe attack results in complete skeletonization and drying up of the leaves within a short time. This has necessitated the management of insect and non-insect pests of amaranthus species. The borers group, curculionids caused infestations up to $12.6 \%$, while the white grubs infested $7.3 \%$ of the plants (Aderolu et al., 2013).

Chemical insecticides played a significant role in plant protection against these pests, especially in commercial amaranthus cultivation. This scenario necessitated the development and application of new chemical insecticides that are more effective in pest control, safer to humans and less harmful to the environment (Korrat et al., 2012). Hence, the study was undertaken with the objective to look into the various patterns of pesticide usage and farmers' knowledge about pest management in amaranthus in different amaranthus growing blocks of Coimbatore district.

\section{MATERIALS AND METHODS}

\section{Study area}

Field survey on pesticide usage pattern in amaranthus was conducted in three amaranthus growing blocks of Coimbatore, viz., Sultanpet block $\left(10.8771^{\circ} \mathrm{N}\right.$ and $\left.77.1974^{\circ} \mathrm{E}\right)$ comprising of villages such as Pappampatti, Edayarpalayam, Kallapalayam, Kammalapatti, Kumarapalayam and Pachapalayam, Karamadai block $\left(11.2428^{\circ} \mathrm{N}\right.$ and $\left.76.9587^{\circ} \mathrm{E}\right)$ comprising of villages such as Mongampalayam, Chinnakallipatti, S Pungampalayam and Mangalakaraiputhur and Thondamuthur block $\left(10.9899^{\circ} \mathrm{N}\right.$ and $\left.76.8409^{\circ} \mathrm{E}\right)$ comprising of villages such as Narasipuram, Viraliyur, Vellimalaipatinam, Madvarayapuram and Theethipalayam) during 2020 - 2021 to study the scenario of pesticide usage in amaranthus growing farms (Table.1).

\section{Research methods}

Farmer surveys, focus group discussions of farmers and key informant interviews were used in amaranthus growing blocks of Coimbatore. Farmers represented various farm sizes (less than one acre to ten acres), levels of production experience and varied insect pest management practices. A questionnaire was prepared and the data on pesticide usage patterns were collected from 15 farmers in each block comprising small to large farmers in the above-mentioned fifteen villages during the survey. The farmer's demographic details, area of cropping, varieties, amaranthus production, information on major pests, major pesticides, spray intervals, insecticide dosage and knowledge on ecofriendly pest management practices were collected. Despite the fact that the farmers in the study area did not maintain farm records, they were able to provide the required information through memory recall and experience. The data on pesticide usage were compiled and analyzed. The information gathered was entered in a MS-Excel worksheet, classified and used for further study. The results of the analyzed data are represented in the form of tables and graphs.

\section{RESULTS AND DISCUSSION}

\section{Demographics of farmers}

A majority of the farmers in the survey were male (68.9\%) compared to female (31.1\%). Landholding of farmers broadly ranges from $<1$ acre to 10 acres. It was found that $48.9 \%$ of respondents had $\leq 1$ acre, while $40 \%$ and $11.1 \%$ had $2-5$ acres and $5-10$ acres, respectively. The literacy rate of respondents was around $37.8 \%$ and rest of the respondents $(62.2 \%)$ were uneducated.

Table 1. List of villages surveyed in Coimbatore district $(n=45)$

\begin{tabular}{ll}
\hline Block & Name of village \\
\hline Pappampatti & Edayarpalayam \\
Kultanpet & Kallapalayam \\
& Kammalapatti \\
& Kumarapalayam \\
& Pachapalayam \\
& Mongampalayam \\
& Chinnakallipatti \\
& S Pungampalayam \\
& Mangalakaraiputhur \\
Karamadai & Narasipuram \\
Viraliyur & Vellimalaipatinam \\
Madvarayapuram & Theethipalayam \\
\hline
\end{tabular}

$107|10-12| 2$ 


\section{Production}

Survey reports revealed that majority of the respondents had obtained the yield ranging from 5 - 7 tonnes of leaf yield per acre and 300 $350 \mathrm{~kg}$ of seed yield per acre. Among the survey participants, $91.1 \%$ had raised amaranthus as monocrop. Whereas, $2.2 \%$ grown it as intercrop and $6.7 \%$ of farmers had both monocrop and intercrop production systems.

Figure 1. Commonly used pesticides in amaranthus

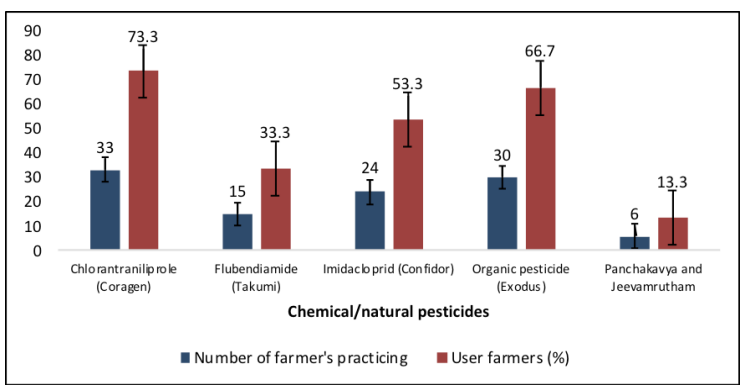

About $42.2 \%$ of respondents used seeds from the previous harvest for sowing and $57.8 \%$ had obtained seed from agricultural supply stores. From the harvested produce, $32.8 \%$ was used for home consumption purposes and the rest $(67.2 \%)$ for sale purposes. Survey results revealed that insect pests $(63.2 \%)$, marketing (22.4\%) and weather parameters (14.4\%) are the major constraints in amaranthus production.

Figure 2. Seasonal abundance of amaranthus pests

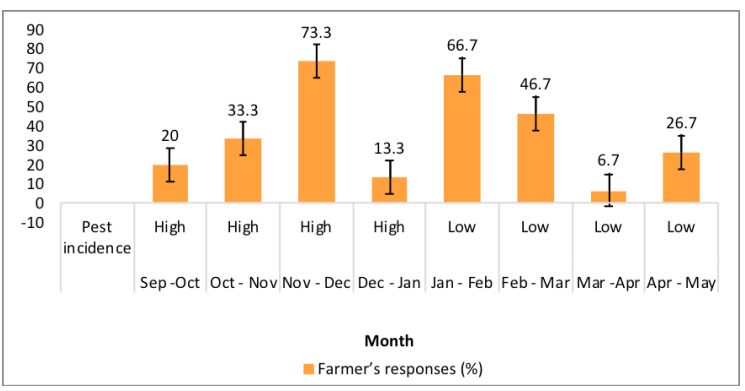

\section{Pest infestation}

Based on the survey, the major variety grown was sengeerai followed by arun red, thandu keerai, arai keerai, C01 and C02. Reports revealed that pests such as leaf webber (Hymenia recurvalis), stem weevil (Hypolixus truncatulus), leaf miner (Liriomyza sp.), ash weevils (Myllocerus discolour and $M$. viridanus), flea beetle (Chaetocnema sp.) and coreid bug (Cletus sp.) were commonly observed in the three respective blocks. Among which leaf webber and ash weevils were found to be major threat to farmers. Damage caused by leaf webber was assessed and represented as percentage. The incidence and intensity of leaf webber was scored using the score chart (Shahiba et al., 2020). Scores were given as 0 - no incidence, 1 - mild (25\%),
2 - medium (50\%), 3 - severe (75\%) and 4 - very severe (100\%). Based on the survey report, leaf webber incidence was observed in all three blocks and based on scoring, high level of pest severity was observed.

Figure 3. Frequency of pesticide usage in amaranthus

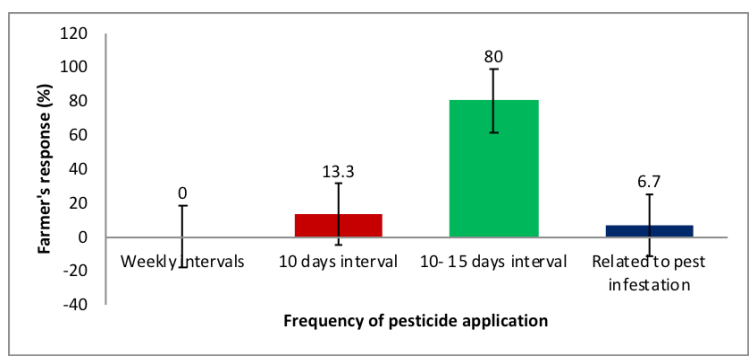

\section{Management practices}

Pesticides commonly used by respondents in amaranthus is listed in Figure 1. Results from the survey revealed that many of the farmers used chlorantraniliprole (73.3 per cent farmer response), followed by the use of organic pesticides (exodus) (66.7 per cent). Muralikrishna et al. (2019) also reported that chlorantraniliprole $(0.006 \%)$ was found to be the most effective insecticide against pests of amaranthus. Other farmers used imidacloprid (53.3 per cent) and flubendiamide (33.3 per cent). Muralikrishna et al. (2021) stated that among various insecticides used, flubendiamide $(0.0096 \%)$ was found to produce promising results in the management of amaranthus pests. Tohnishi et al. (2005) also reported that flubendiamide had greater efficacy in managing lepidopteran insect pests in amaranthus. Because of the specific mode of action of these diamides, all the treated larvae stopped feeding on amaranth leaves within six hours of exposure, despite the fact that flubendiamide $(0.0096 \%)$ and chlorantraniliprole $(0.006 \%)$ treated larvae took 36 hours to cause cent per cent mortality. This is due to diamides greater insecticidal efficacy against a variety of lepidopteran pests and many other insect orders, including Coleoptera, Diptera, Isoptera and Hemiptera (Sattelle et al., 2008; Lahm et al., 2009). Safety of diamides to spiders was also reported by Rajavel (2011). Only 13.33 per cent of respondents had used panchakavya and jeevamrutham for managing the pests.

Farmer's perception on seasonal abundance of amaranthus pests as recorded during the survey in three blocks of Coimbatore is given in Figure 2. The abundance of pest population was maximum during the month of November - December (73.3 per cent farmer response) followed by October November (33.3 per cent). Aderolu et al. (2013) also reported that the pest population of amaranthus was abundant on dry season during the month of November and December. There was no significant 
difference in the abundance of leaf webbers and leaf worms between the dry and wet seasons (Othim et al., 2018). Pest population abundance was the lowest during January - February (66.7 per cent) followed by February - March (46.7 per cent). Majority of the respondents used power sprayers to apply pesticides in all the three blocks.

Figure 4. Dosage of insecticide used by farmers in amaranthus

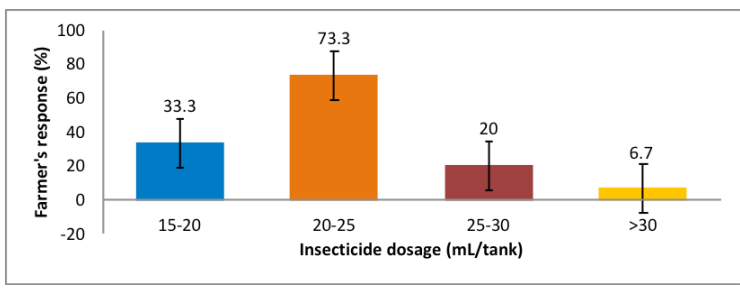

Farmer's response on the frequency of pesticides usage in amaranthus is shown in Figure 3. It indicated that eighty per cent of farmers applied pesticides at 10-15 days intervals, whereas 13.3 per cent of the farmers sprayed at 10 days interval and none of the farmers surveyed, sprayed at weekly intervals. The remaining 6.7 percent of farmers apply pesticides based on insect infestation.

The insecticide dosage used by farmers in amaranthus is shown in Figure 4. Majority of the farmers had used insecticides at the dosage of 20$25 \mathrm{~mL}$ per tank (73.3 per cent) followed by $15-20$ $\mathrm{mL}$ per tank (33.3 per cent) and $25-30 \mathrm{~mL}$ per tank (20.0 per cent) during the cropping period.

Figure 5. Sourcing of information on pesticide usage

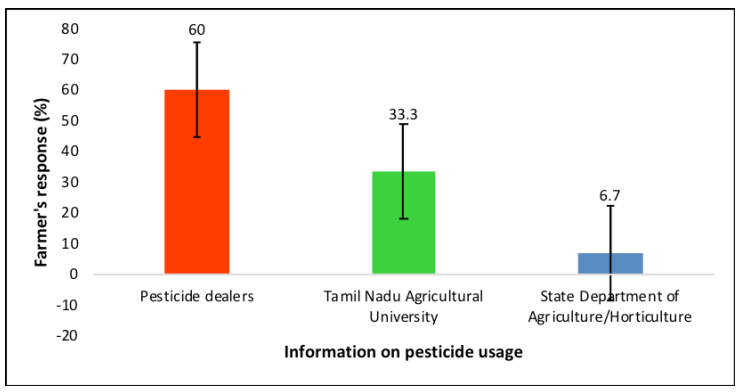

Most of the respondents were not aware of predators and parasitoids. Sourcing of information on pesticide usage in amaranthus pest management was obtained from the pesticide dealers (60 per cent), TNAU (33.3 per cent) and State Department of Agriculture (6.7 per cent) (Figure 5). The most important source of knowledge for farmers about pesticide use were notifications from agrochemical stores, as well as sales representatives from various agrochemical firms.

\section{CONCLUSION}

The findings confirmed that amaranthus growing farmers were facing several pest problems. The majority of the farmers used chlorantraniliprole at 10-15 days intervals for controlling the pests. The results revealed that to increase production and productivity, most of the farmers used chemical insecticides to manage the pests rather than employing bio-control agents. For the betterment of the consumers and to enhance the production and productivity of this green leafy vegetable, research on the development of integrated pest management module for amaranthus is need of the hour, which could increase the production of amaranthus by proper identification of pests, use of pesticides at the right time and dose and development of alternative eco-friendly pest management strategies.

\section{Declarations}

The authors declare that the work carried out in this research paper is the original work carried out by the first author as part of the thesis research and has not been published earlier or sent for publication to other research journals.

\section{Ethics statement}

Specific permits were not required for the above field studies because no human or animal subjects were involved in this research.

\section{Consent for publication}

All the authors agreed to publish the content.

\section{Competing interests}

There was no conflict of interest in the publication of this content.

\section{Data availability}

All the data of this manuscript are included in the manuscript. No separate external data source is provided. If any data is required from the manuscript, certainly, it will be extended by communicating with the first author through mail: kalaielakkiya98@ gmail.com

\section{REFERENCES}

Akubugwo, I. E., Obasi, N. A., Chinyer, G. C. and A. E. Ugbogu. 2007. Nutritional and chemical value of Amaranthus hybridus L. leaves from Afikpo, Nigeria. Afr. J. Biotechnol., 6(24): 2833-2839.

Achigan-Dako, E. G., Sogbohossou, O. E. and P. Maundu. 2014. Current knowledge on Amaranthus spp.: research avenues for improved nutritional value and yield in leafy amaranths in sub-Saharan Africa. Euphytica., 197(3): 303-317.

Aderolu, I. A., Omooloye, A. A. and F. A. Okelana. 2013. Occurrence, abundance and control of the major insect pests associated with amaranths in Ibadan, Nigeria. Entomol Ornithol Herpetol., 2(112): 21610983.

Ezeh, A. E., Ogedegbe, A. B. O. and S. A. Ogedegbe. 2015. Insect pest occurrence on cultivated 
Amaranthus spp in Benin City, Edo State, Nigeria. J. Appl. Sci. Environ. Manage., 19(2): 335-339.

Kaaya, A., Kyamuhangire, W., Nakimbugwe, D., Chen, J. and R. Phillips. 2017. Efforts to promote amaranth production and consumption in Uganda to fight malnutrition. African J. Food, Agric. Nutr. Dev., 17: 12758-12774.

Kagali, R. N., Kioko, E. N., Osiemo, Z., Muya, S. and C. Wachera. 2013. Insect abundance and diversity on cultivated Amaranthus Sp. (Amaranthaceae) in Meru County, Kenya. Am. Int. J. Contemp. Res., $3(7)$.

Kamalanathan, S., Sunderajan, S., Thambura, J. S. and A. Shanmugam. 1973. Co I Amaranthus. A high yielding and delicious strain. Madras Agric. J., 60(6): 355-358.

Korrat, E. E. E., Abdelmonem, A. E., Helalia, A. A. R. and H. M. S. Khalifa. 2012. Toxicological study of some conventional and nonconventional insecticides and their mixtures against cotton leaf worm, Spodoptera littoralis (Boisd.) (Lepidoptera: Noectudae). Ann. Agric. Sci., 57(2): 145-152.

Lahm, G. P., Cordova, D. and J. D. Barry. 2009. New and selective ryanodine receptor activators for insect control. Bioorg. Med. Chem., 17(12): 4127-4133.

Martirosyan, D. M., Miroshnichenko, L. A., Kulakova, S. N., Pogojeva, A. V. and V. I. Zoloedov. 2007. Amaranth oil application for coronary heart disease and hypertension. Lipids Health Dis., 6(1): 1-12.

Muralikrishna, P., Mathew, T. B., Paul, A. and P. R. Nithya. 2019. Evaluation of bio-efficacy of new generation insecticides, botanicals and microbial insecticides on leaf webber of amaranth. J. Entomol. Zool. Stud., 7(5): 516-520.
Muralikrishna, P., Mathew, T. B., Nithya, P. R. and A. Paul. 2021. Bio-efficacy of new generation insecticides, botanicals, and microbial insecticides on Spodoptera litura. F (Lepidoptera: Noctuidae) in amaranth. J. Entomol. Zool. Stud., 9(3): 183-186.

Othim, S. T. O., Kahuthia-Gathu, R., Akutse, K. S., Foba, C. N. and K. K. M. Fiaboe. 2018. Seasonal occurrence of amaranth Lepidopteran defoliators and effect of attractants and amaranth lines in their management. J. Appl. Entomol., 142(7): 637-645.

Othim, S. T. O., Srinivasan, R., Kahuthia-Gathu, R., Dubois, T., Dinssa, F., Ekesi, S. and K. K. M. Fiaboe. 2018. Screening for resistance against major lepidopteran and stem weevil pests of amaranth in Tanzania. Euphytica., 214(10): 1-21.

Rajavel, D. S., Mohanraj, A. and K. Bharathi. 2011. Efficacy of chlorantraniliprole (Coragen 20SC) against brinjal shoot and fruit borer, Leucinodes orbonalis (Guen.). Pest Manag. Hort. Ecosyst., 17(1): 28-31.

Sattelle, D. B., Cordova, D. and T. R. Cheek. 2008. Insect ryanodine receptors: molecular targets for novel pest control chemicals. Invert. Neurosci., 8(3): 107-119.

Shahiba, A. M., Thomas, B., and A. Chacko. 2020. Evaluation of Thirty Amaranthus Genotypes (Amaranthus tricolor L.) for Different Biometric Characters. Int. J. Curr. Microbiol. App. Sci., 9(8): 1621-1631.

Tohnishi, M., Nakao, H., Furuya, T., Seo, A., Kodama, H., Tsubata, K., Fujioka, S., Kodama, H., Hirooka, T. and T. Nishimatsu. 2005. Flubendiamide, a novel insecticide highly active against lepidopterous insect pests. J. Pestic. Sci., 30(4): 354-360. 